\title{
PENGARUH FINANCIAL LITERACY, FINANCIAL KNOWLEDGE, FINANCIAL ATTITUDE, INCOME DAN FINANCIAL SELF EFFICACY TERHADAP FINANCIAL MANAGEMENT BEHAVIOR ENTREPRENEUR LULUSAN PERGURUAN TINGGI DI SURABAYA
}

\author{
Anglia Dinda Pramedi \\ Universitas Negeri Surabaya \\ angliadindapramedi@gmail.com \\ Nadia Asandimitra \\ Universitas Negeri Surabaya \\ nadiaharyono@unesa.ac.id
}

Abstract

\begin{abstract}
Finance is one of the factors in the development of a business. Therefore, the entrepreneur should be able to handle finances well to reach business purposes. Based on the previous studies, the purpose of this research is to determine the effect of several factors such as financial literacy, financial knowledge, financial attitude, income, and financial self-efficacy on financial management behavior. The research sample is 211 entrepreneur who has graduated from college in Surabaya. This research used conclusive causality research with primary data. The sampling technique used purposive sampling and snowball sampling method, and data distribution using an online questionnaire. SEM (Structural Equation Model) used for data analysis technique and using AMOS 24. The hypothesis showed that financial knowledge, income, and financial self-efficacy did not affect financial management behavior, but financial literacy and financial attitude influence financial management behavior. Therefore, the entrepreneur needs to improve financial literacy and financial attitude to manage finance on the business better.
\end{abstract}

Keywords: financial attitude; financial literacy; financial management behavior; financial self efficacy; income.

\section{PENDAHULUAN}

Seiring dengan perkembangan jaman dan teknologi, kebutuhan manusia akan semakin meningkat dan ekonomi terus mengalami pertumbuhan dan perubahan. Selaras dengan hal tersebut, menurut data yang bersumber dari Dukcapil Kemendagri, jumlah penduduk di Indonesia mengalami kenaikan sebesar 0,77\% per 30 Juni 2020 dengan total 268.583.016 Jiwa (Nugraheny \& Meiliana, 2020). Dari jumlah tersebut terdapat 7,05 juta pengangguran dan terus meningkat dari hari ke hari diiringi dengan semakin banyaknya lulusan tenaga terdidik. Sedangkan lapangan pekerjaan di Indonesia hanya ada 2 juta angkatan kerja baru setiap tahunnya (Kementerian Koperasi dan UKM, 2020). Hal ini diakibatkan lulusan tenaga terdidik yang ingin menjadi pencari kerja bukan menciptakan lapangan kerja. Di Indonesia tingkat pengangguran lulusan diploma sebesar 5,99\% dan sarjana sebesar 5,67\% (Ulya \& Sukmana, 2019). Sedangkan di Jawa Timur tingkat pengangguran tenaga terdidik perguruan tinggi sebesar 3,84\% dari total 6\% tingkat global pengangguran di Jawa Timur (Redaksi, 2019).

Usaha pemerintah untuk menurunkan angka pengangguran yang ada di Indonesia yaitu meningkatkan jumlah UMKM, yang merupakan faktor pendorong perekonomian Indonesia. Sektor UMKM memberi andil terhadap kemajuan ekonomi, pembentukan produk domestik bruto (PDB), sumber ekspor nonmigas, serta penciptaan lapangan pekerjaan dan penyerapan tenaga kerja. Terbukti pada 2018 sebesar 97\% tenaga kerja atau sebanyak 117 juta pekerja diserap oleh UMKM, sedangkan sisanya 3\% diserap oleh korporasi (Purwanto, 2020).

Beberapa hal yang dilakukan pemerintah dalam bidang pendidikan untuk mendorong peningkatan jumlah UMKM, yaitu mengadakan Program Mahasiswa Wirausaha (PMW), Pekan Kreatifitas Mahasiswa (PKM) (Dirjen Dikti Kemendikbud, 2020) serta memasukkan mata pelajaran kewirausahaan ke dalam kurikulum pendidikan (Budiarto, 2015). Upaya ini dilakukan untuk meningkatkan keinginan dan kesempatan mahasiswa dalam berwirausaha ketika lulus dari perguruan 
Anglia Dinda Pramedi \& Nadia Asandimitra Haryono. Pengaruh Financial Literacy, Financial Knowledge, Financial Attitude, Income dan Financial Self Efficacy terhadap Financial Management Behavior Entrepreneur Lulusan Perguruan Tinggi di Surabaya

tinggi dan sebagai usaha mengurangi tingkat pengangguran pada lulusan perguruan tinggi. Selain itu, pemerintah melalui Kementerian Koperasi dan UKM (2020), menyatakan terdapat enam program yang tepat bagi UMKM: ekspansi pasar; daya saing yang kompetitif; peningkatan kewirausahaan; percepatan pembiayaan; kemudahan dan kesempatan berusaha, dan koordinasi lintas sektor.

Walaupun menurut kementerian koperasi dan UKM (2020) tingkat wirausaha di Indonesia masih sebesar 3,5\% dari total penduduk, usaha pemerintah tersebut terbukti berhasil karena UMKM di Indonesia selalu mengalami pertumbuhan setiap tahunnya. Seperti yang ditunjukkan gambar 1, tahun 2010 jumlah UMKM di Indonesia sebanyak 52.769.426 dan pada tahun 2011 meningkat menjadi 54.119.971 hingga pada tahun 2018 jumlah UMKM mencapai 64.199.607 UMKM (Kementerian Koperasi dan UKM, 2018). Dari jumlah 64.19 juta, terdapat 63,35 juta usaha mikro atau sebesar 98,68\% dari total UMKM, disusul dengan usaha kecil sebesar 1,22\% atau sebanyak 783.132 usaha sedangkan pada usaha menengah terdapat 60.702 usaha atau sebesar 0,09\% (Purwanto, 2020).

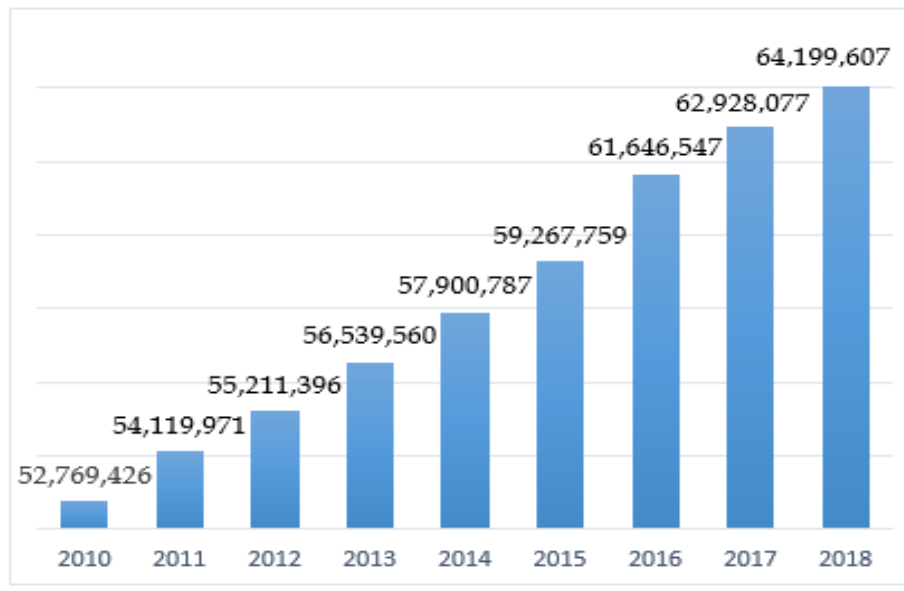

Sumber: Kementerian Koperasi dan UKM

Gambar 1. DATA PERTUBUHAN UMKM DI INDONESIA TAHUN 2010-2018

Karena pertumbuhan UMKM ini menyebabkan persaingan di dunia usaha, maka upaya pemerintah tersebut perlu didorong oleh faktor-faktor pendukung yang dimiliki individu dalam mempertahankan usahanya agar dapat berjalan dengan baik. Salah satu faktor yang dibutuhkan yaitu keterampilan dalam pengambilan keputusan yang tepat dengan perilaku manajemen keuangan yang dimiliki sehingga pendapatan dengan pengeluaran dapat seimbang dan pengelolaan keuangan dapat berjalan dengan baik. Hal ini sangat bermanfaat dan menunjang keberlangsungan usaha terutama pada wirausahawan yang baru merintis (Rizkiawati \& Asandimitra, 2018).

Financial management behavior merupakan keinginan individu dalam mencukupi keperluan hidupnya yang didasari oleh hasil usaha yang didapatkan (Kholilah \& Iramani, 2013). Sedangkan Rizkiawati \& Asandimitra, (2018) mengemukakan financial management behavior yaitu kemampuan individu dalam membuat rencana, membuat anggaran, mengelola, mengontrol, pencarian, serta menyisihkan keuangan sehari-hari. Terdapat tiga faktor yang bisa memengaruhi financial management behavior antara lain financial attitude, financial knowledge, serta income (Mahgfiroh et al., 2020). Selain itu Herawati et al. (2018).menyatakan terdapat faktor financial literacy dan financial self efficacy yang juga dapat memengaruhi financial management behavior.

Literasi keuangan menjadi salah satu permasalahan penting dalam manajemen keuangan. Tahun 2019 OJK mengadakan survei untuk mengetahui tingkat literasi keuangan penduduk Indonesia, hasil yang didapat membuktikan bahwa literasi keuangan penduduk Indonesia masih cukup rendah, yaitu sebesar $38 \%$ (Kencana, 2020). 
Financial literacy merupakan kemampuan seseorang akan keuangan yang dapat dimanfaatkan sebagai salah satu dasar pengambilan keputusan, sehingga berguna dalam peningkatan perekonomian di masa mendatang (Dayanti et al., 2020). Semakin tinggi tingkat pemahaman tentang keuangan maka tanggung jawab dan pengambilan keputusan juga akan meningkat lebih baik, dan hal ini dapat memengaruhi pengelolaan keuangan (Ida et al., 2020). Menurut Prihartono \& Asandimitra (2018), financial literacy memberi pengaruh kepada financial management behavior. Sedangkan Purwidianti \& Tubastuvi (2019) financial literacy tidak memengaruhi financial management behavior.

Financial knowledge atau pengetahuan keuangan ialah suatu keterampilan yang dimiliki seseorang mengenai berbagai hal yang berhubungan dengan keuangan (Putri \& Pamungkas, 2019). Jika tingkat financial knowledge seseorang baik, maka pengelolaan keuangan juga akan baik (Rahmawati \& Haryono, 2020). Semakin banyak pengetahuan yang dimiliki akan membuat pengetahuan tersebut menjadi faktor pertimbangan dalam membuat keputusan, Maka keputusan yang nantinya akan dipilih merupakan langkah yang bijak dan tepat (Rizkiawati \& Asandimitra, 2018). Pernyataan tersebut juga selaras dengan pernyataan yang dikemukakan Dayanti et al. (2020) di mana pengetahuan keuangan memberi pengaruh yang positif terhadap pengelolaan keuangan seseorang. Namun, hasil yang berbeda didapatkan oleh Prihartono \& Asandimitra (2018) di mana financial knowledge tidak bisa memengaruhi oleh financial management behavior.

Financial attitude mengarah pada cara individu dalam mengatur perilaku pengelolaan keuangan dan bagaimana individu tersebut dapat melakukan pengambilan keputusan yang berkaitan dengan manajemen keuangannya (Nobriyani \& Haryono, 2019). Pada financial attitude, semakin baik pola pikir yang diterapkan akan menimbulkan nilai positif pada seseorang dan penilaian positif tersebut dapat memengaruhi pengelolaan keuangan yang semakin bijak (Rizkiawati \& Asandimitra, 2018). Menurut penelitian Mahgfiroh et al. (2020), menunjukkan ada pengaruh signifikan dan positif yang dihasilkan financial attitude terhadap financial management behavior. Tetapi, pada hasil penelitian Yap et al. (2016) menunjukkan financial attitude tidak memengaruhi financial management behavior.

Varibel lainnya yang dapat memengaruhi pengelolaan keuangan adalah income. Income merupakan suatu penghasilan yang muncul atas aktivitas penjualan, imbalan, bunga, royalti, dividen dan sewa (Sodikin \& Riyono, 2014). Semakin tinggi pendapatan yang dimiliki seseorang, maka tanggungjawab atas keuangan juga lebih besar. Hal tersebut membuat seseorang dapat mengambil keputusan secara tepat dan melakukan pengelolaan keuangan dengan lebih baik (Rizkiawati \& Asandimitra, 2018). Hal ini sesuai dengan penelitian milik Masdupi \& Rasyid (2020) di mana terdapat pengaruh positif yang dihasilkan oleh income terhadap financial management behavior. Namun Arifin (2019) mengemukakan bahwa income tidak mampu memengaruhi financial management behavior.

Financial self efficacy merupakan suatu tingkat keyakinan diri atau kepercayaan yang dimiliki oleh individu mengenai kemampuannya dalam mencapai tujuan keuangan. Jika tingkat kepercayaan akan keuangan yang dimiliki seseorang tinggi, maka rasa tanggung jawab seseorang tersebut juga akan meningkat dalam mengelola keuangan (Rizkiawati \& Asandimitra, 2018). Menurut Herawati et al. (2018), financial self efficacy dapat memengaruhi financial management behavior seseorang. Tetapi, hal tersebut bertentangan dengan Nobriyani \& Haryono (2019) di mana financial self efficacy tidak memberi pengaruh kepada financial management behavior. Tujuan penelitian ini yaitu untuk mengetahui pengaruh financial literacy, financial knowledge, financial attitude, income dan financial self efficacy terhadap financial management behavior Entrepreneur lulusan perguruan tinggi di Surabaya.

\section{KAJIAN PUSTAKA DAN PENGEMBANGAN HIPOTESIS}

\section{Theory of Planned Behavior}

Theory of Planned Behavior (TPB) merupakan suatu teori untuk memprediksi perubahan perilaku seseorang (Ajzen, 1991). Faktor utama yang memengaruhi perilaku seseorang menurut theory of planned behavior adalah niat dan tujuan. Selain itu, latar belakang individu juga salah satu faktor 
Anglia Dinda Pramedi \& Nadia Asandimitra Haryono. Pengaruh Financial Literacy, Financial Knowledge, Financial Attitude, Income dan Financial Self Efficacy terhadap Financial Management Behavior Entrepreneur Lulusan Perguruan Tinggi di Surabaya

yang memengaruhi perilaku seseorang. Terdapat tiga faktor yang menjadi latar belakang individu seseorang, yaitu personal yang menggambarkan perilaku seseorang akan suatu hal, pandangan hidup, kecerdasan, emosi dan kepribadian individu; sedangkan sosial meliputi pendidikan, pendapatan, umur, etnis, jenis kelamin, agama dan suku; informasi yang meliputi pengetahuan, pengalaman pribadi dan berita di media (Ajzen, 2005)

\section{Social Cognitive Theory}

Social cognitive theory berasal dari pandangan human agency yang didasari oleh pernyataan "bahwa proses kognitif maupun proses sosial merupakan pusat untuk memahami suatu emosi, motivasi maupun pemahaman atas tindakan manusia" (Bandura, 1977). Terbentuknya self efficacy atau efikasi diri merupakan salah satu bagian cukup penting dalam human agency. Menurut Bandura (1977), efikasi diri bukan sekedar untuk mengerti apa saja yang perlu diperbuat, namun dibutukan suatu keterampilan dan rasa percaya diri akan kemampuannya dalam melakukan suatu kinerja. Memiliki suatu kepercayaan akan self efficacy sangat berpengaruh terhadap cara berperilaku individu.

\section{Financial Management Behavior}

Financial management behavior merupakan kemampuan seseorang untuk mengelola dan menganggarkan keuangan sehingga dapat mengambil keputusan yang tepat atas kondisi keuangannya (Rizkiawati \& Asandimitra, 2018). Menurut Rahmawati \& Haryono (2020), financial management behavior merupakan cara seseorang mempelajari perilakunya dalam mengatur keuangan melalui kebiasaan dan perspektif intelektualnya. Untuk mengetahui perilaku pengelolaan keuangan individu, terdapat lima indikator yang digunakan yakni pengontrolan keuangan, pembayaran tagihan, perencanaan keuangan, penyediaan uang, penyimpanan uang (Ida \& Dwinta, 2010).

\section{Financial Literacy}

Financial literacy merupakan pemahaman akan keuangan yang dapat digunakan seseorang dalam pengambilan suatu keputusan untuk meningkatkan ekonomi di masa mendatang (Dayanti et al., 2020). Menurut Yap et al. (2016), financial literacy memberikan pengetahuan yang menjadikan individu memahami apa, bagaimana, di mana, mengapa, dan kapan harus melakukan tindakan yang berhubungan dengan keuangan. Menurut Otoritas Jasa Keuangan (2014), terdapat empat tingkatan financial literacy masyarakat Indonesia, yang pertama yaitu well literate sebesar 21,84\%, tingkatan berikutnya yaitu sufficient literate sebesar 75,69\%, tingkatan ketiga adalah less literate sebesar 2,06\% dan yang terakhir not literate sebesar $0,41 \%$. Beberapa dimensi financial literacy menurut Chen \& Volpe (1998) yakni pengetahuan umum keuangan, tabungan, asuransi, pinjaman dan investasi.

\section{Financial Knowledge}

Financial knowledge yaitu kemampuan yang dimiliki oleh setiap individu tentang segala kegiatan yang berkaitan dengan pengelolaan keuangan yang berlaku dalam aktivitas setiap hari. Untuk memiliki pengetahuan akan keuangan yang baik, maka individu perlu meningkatkan financial skill dan mampu dalam penggunaaan financial tools (Ida \& Dwinta, 2010). Financial skill ialah suatu teknik yang bermanfaat sebagai dasar membuat suatu keputusan dalam manajemen keuangan pribadi maupun pada usaha (Ida \& Dwinta, 2010). Sedangkan financial tools merupakan alat yang dapat dimanfaatkan untuk menunjang membuat suatu keputusan keuangan sepeti kartu debit, kartu kredit dan cek (Garman \& Forgue, 1985). Menurut Ida \& Dwinta (2010) pengukuran financial knowledge menggunakan indikator yang meliputi pengetahuan terhadap: suku bunga, pinjaman atau kredit, pengelolaan keuangan, investasi, laporan keuangan pribadi.

\section{Financial Attitude}

Financial atitude yaitu suatu kondisi di mana seseorang menerapkan pemikiran, pendapat dan penilaian terhadap keuangan dalam sebuah tindakan (Humaira \& Sagoro, 2018). Terdapat lima hal yang menjadi indikator financial attitude yaitu pentingnya untuk mengontrol pengeluaran, pentingnya untuk menabung secara teratur, pentingnya membandingkan manfaat layanan instrumen keuangan yang digunakan, pentingnya memiliki dana cadangan, serta pentingnya menetapkan sebuah anggaran (Sugiyanto et al., 2019). 


\section{Income}

Menurut Sodikin \& Riyono (2014) pendapatan usaha atau income merupakan penghasilan yang muncul atas aktivitas penjualan, imbalan, bunga, royalti, dividen dan sewa. Berdasarkan UU Nomor 20 Tahun 2008 mengenai Usaha Mikro Kecil Menengah (UMKM) terdapat 3 indikator pendapatan atau omzet per tahun pada UMKM yaitu usaha mikro ( $<300$ juta rupiah), usaha kecil (300 juta rupiah - 2,5 miliar rupiah) dan usaha menengah (2,5 miliar rupiah - 50 miliar rupiah) (Otoritas Jasa Keuangan, 2017).

\section{Financial Self Efficacy}

Self efficacy yaitu suatu kepercayaan atau keyakinan yang dimiliki oleh individu mengenai kemampuan dalam mengelola sebuah tindakan untuk mencapai suatu tujuan (Bandura, 1977). Financial self efficacy adalah suatu keyakinan individu terkait kemampuan dalam pengelolaan keuangan sesuai tujuan usahanya (Forbes \& Kara, 2010). Indikator financial self efficacy menurut Lown (2011) yaitu keahlian merencanakan pengeluaran keuangan, keahlian mencapai tujuan, keahlian mengambil keputusan disituasi tidak terduga, keahlian dalam menghadapi tantangan keuangan, kepercayaan terhadap kondisi keuangan masa depan, dan kepercayaan dalam pengelolaan keuangan.

\section{Hubungan Antar Variabel}

Theory of planned behavior mendasari hubungan financial literacy dan financial management behavior bahwa individu dalam berperilaku dikarenakan mempunyai niat atau tujuan ketika melakukannya, hal ini disebabkan oleh faktor informasi, di mana financial literacy termasuk ke dalam faktor informasi tersebut (Ajzen, 1991). Pada financial literacy, semakin tinggi tingkat pemahaman tentang keuangan maka tanggung jawab dan pengambilan keputusan juga akan semakin baik dan hal ini dapat memengaruhi pengelolaan keuangan yang lebih bijak (Ida et al., 2020). Hal tersebut selaras dengan Dayanti et al. (2020) di mana financial literacy memberi pengaruh yang signifikan terhadap financial management behavior. Apabila individu mempunyai financial literacy yang cukup tinggi, maka individu tersebut menjadi lebih teliti dalam mengelola keuangan untuk mencapai tujuan usahanya. Selain itu, Prihartono \& Asandimitra (2018); Yap et al. (2016); dan Herawati et al. (2018) juga menyatakan bahwa financial literacy dapat memengaruhi seseorang dalam mengelola keuangan. Namun, berbeda dengan Purwidianti \& Tubastuvi (2019) financial literacy tidak berpengaruh secara signifikan terhadap financial management behavior, sehingga apabila individu mempunyai financial literacy yang baik, tidak menjamin individu tersebut mampu mengelola keuangan dengan bijak.

H1: Terdapat pengaruh financial literacy terhadap financial management behavior entrepreneur lulusan perguruan tinggi di Surabaya.

Theory of planned behavior juga mendasari pengaruh financial knowledge terhadap financial management behavior (Ajzen, 1991). Dalam teori tersebut, individu dalam berperilaku mempunyai niat atau tujuan ketika melakukannya yang dilatarbelakangi oleh faktor informasi. Di mana dalam theory of planned behavior, financial knowledge termasuk ke dalam faktor informasi tersebut (Ajzen, 1991). Semakin tinggi financial knowledge yang dimiliki oleh individu, maka individu tersebut akan mampu dalam mengambil suatu keputusan yang lebih bijak, sehingga pengelolaan keuangan yang dihasilkan jauh lebih baik (Rizkiawati \& Asandimitra, 2018). Nobriyani \& Haryono (2019) juga menyatakan bahwa pengetahuan keuangan mempunyai pengaruh atas pengelolaan keuangan. Hal ini menunjukkan tinggi rendahnya pengetahuan keuangan yang dimiliki oleh individu, akan memengaruhi perilaku individu tersebut dalam pengelolaan keuangan usahanya. Hal tersebut sejalan dengan penelitian Dayanti et al. (2020); Ramadhan \& Asandimitra (2019); Mahgfiroh et al. (2020); Rahmawati \& Haryono (2020); Rosyadah (2020); Komaria \& Ratnawarti (2018); Adiputra \& Patricia (2020); Arifin (2019); Mien \& Thao (2015); Masdupi \& Rasyid (2020); dan Siswanti \& Halida (2020). Namun, hal berbeda ditunjukkan oleh Rizkiawati \& Asandimitra (2018) dan Prihartono \& Asandimitra (2018), financial knowledge tidak dapat memengaruhi financial management behavior.

$\mathrm{H} 2$ : Terdapat pengaruh financial knowledge terhadap financial management behavior entrepreneur lulusan perguruan tinggi di Surabaya. 
Anglia Dinda Pramedi \& Nadia Asandimitra Haryono. Pengaruh Financial Literacy, Financial Knowledge, Financial Attitude, Income dan Financial Self Efficacy terhadap Financial Management Behavior Entrepreneur Lulusan Perguruan Tinggi di Surabaya

Hubungan financial attitude dengan financial management behavior dilatarbelakangi oleh theory of planned behavior, bahwa seseorang dalam bertindak dikarenakan memiliki niat atau tujuan ketika melakukannya, hal ini didasari oleh faktor pribadi yang salah satunya yaitu attitude (Ajzen, 1991). Perilaku keuangan sangat berkaitan dengan pengelolaan keuangan karena semakin bijak perilaku yang dimiliki oleh individu maka pengelolaan keuangan juga akan baik (Mahgfiroh et al., 2020). Siswanti \& Halida (2020) menyatakan hasil yang signifikan pengaruh financial attitude terhadap financial management behavior, pernyataan tersebut membuktikan bahwa seseorang yang memiliki pemikiran rasional dan percaya diri dalam masalah keuangan, akan dapat memengaruhi pengelolaan diri seseorang yang lebih baik. Hasil serupa ditunjukkan Ramadhan \& Asandimitra (2019); Dayanti et al. (2020); Mahgfiroh et al. (2020); Rahmawati \& Haryono (2020); Rosyadah (2020); Adiputra \& Patricia (2020); Prihartono \& Asandimitra (2018); Yap et al. (2016); dan Mien \& Thao (2015). Hasil berbeda ditunjukkan Nobriyani \& Haryono (2019) dan Rizkiawati \& Asandimitra (2018) bahwa perilaku keuangan tidak dapat memengaruhi perilaku manajemen keuangan, hal tersebut dikarenakan para responden mempunyai pendapat dan cara menyikapi yang berbeda-beda.

H3: Terdapat pengaruh financial attitude terhadap financial management behavior entrepreneur lulusan perguruan tinggi di Surabaya.

Theory of planned behavior mendasari pengaruh income terhadap financial management behavior, Sesorang dalam berperilaku mempunyai niat dan tujuan untuk melaksanakannya, hal tersebut disebabkan oleh faktor pendapatan (Ajzen, 1991). Semakin besar income yang didapat, maka memengaruhi seseorang dalam berperilaku terhadap keuangan yang lebih bertanggung jawab (Rizkiawati \& Asandimitra, 2018). Pernyataan tersebut diperkuat oleh Masdupi \& Rasyid (2020) bahwa income dapat memengaruhi financial management behavior seseorang, karena income mampu membentuk perilaku seseorang dalam mengatasi masalah keuangan. Komaria \& Ratnawarti (2018), income dapat memberi pengaruh signifikan positif terhadap financial management behavior. Artinya jika individu memiliki pendapatan yang terbilang tinggi, maka memungkinkan seseorang tersebut untuk mengalokasikan pendapatan secara bertanggung jawab agar dapat mencapai sebuah tujuan keuangan yang baik dan optional. Mahgfiroh et al. (2020); Komaria \& Ratnawarti (2018); dan Prihartono \& Asandimitra (2018) mendapatkan hasil yang sama, sedangkan Rahmawati \& Haryono (2020); Adiputra \& Patricia (2020); Rizkiawati \& Asandimitra (2018); dan Arifin (2019) menyatakan hasil yang berbeda, income tidak dapat memengaruhi perilaku manajemen keuangan.

H4: Terdapat pengaruh income terhadap financial management behavior entrepreneur lulusan perguruan tinggi di Surabaya.

Financial self efficacy mengacu pada social cognitive theory. Individu perlu mempunyai sebuah keterampilan dan rasa percaya diri akan keahlian yang dimiliki. Semakin tinggi tingkat keyakinan diri akan keuangan, maka tanggung jawab dalam mengelola keuangan juga meningkat (Rizkiawati \& Asandimitra, 2018). Menurut Putri \& Pamungkas (2019), financial self efficacy memengaruhi financial manajemen behavior. Keyakinan yang tinggi akan keuangan dapat memberikan pengaruh dalam mengelola keuangan yang lebih baik. Herawati et al. (2018) mengatakan terdapat pengaruh financial self efficacy terhadap financial management behavior. Tetapi hasil berbeda ditunjukkan Nobriyani \& Haryono (2019) financial self efficacy tidak memengaruhi financial management behavior seseorang, karena terdapat individu lain yang bisa diandalkan dalam pengelolaan keuangan.

H5: Terdapat pengaruh financial self efficacy terhadap financial management behavior entrepreneur lulusan perguruan tinggi di Surabaya.

\section{METODE PENELITIAN}

Jenis penelitian ini yaitu konklusif kausalitas untuk mengetahui pengaruh variabel independen yaitu financial literacy, financial knowledge, financial attitude, income dan financial self efficacy dengan variabel dependen yaitu financial management behavior para entrepreneur. Populasi yang digunakan 
adalah para entrepreneur yang telah lulus dari perguruan tinggi di Surabaya. Purposive sampling dan snowball sampling digunakan dalam pengambilan sampel dengan teknik pengumpulan data yaitu kuesioner online. Kriteria yang digunakan dalam penentuan sampel yakni alumni perguruan tinggi di Surabaya dan menjadi seorang entrepreneur atau memiliki sebuah usaha. Skala likert dan skala guttman digunakan untuk mengukur indikator pada pernyataan dan pertanyaan yang diajukan kepada responden. Jumlah data responden yang terkumpul sebanyak 227 dengan rincian 4 responden tidak lolos pada kategori alumni universitas di Surabaya dan 12 responden tidak lolos pada kategori entrepreneur atau memiliki suatu usaha, sehingga data yang dapat digunakan sebanyak 211 responden. SEM (Structural Equation Model) digunakan sebagai teknik analisis data yang diawali dengan tahap pengujian validitas dan reliabilitas menggunakan program SPSS. Setelah data dapat dikatakan valid dan reliabel, maka langkah selanjutnya yaitu pengujian outlier dan normalitas, dilanjutkan uji kelayakan model dan uji hipotesis dengan program AMOS 24.

\section{HASIL DAN PEMBAHASAN}

Tabel 1.

\section{KARAKTERISTIK RESPONDEN}

\begin{tabular}{|c|c|c|}
\hline \multicolumn{2}{|r|}{ Karakteristik Responden } & \multirow{3}{*}{$\begin{array}{c}\text { Persentase } \\
45 \% \\
55 \%\end{array}$} \\
\hline & Laki-Laki & \\
\hline Jenis Kelamin & Perempuan & \\
\hline \multirow{4}{*}{ Umur } & $<19$ tahun & $0 \%$ \\
\hline & 20 - 34 Tahun & $99 \%$ \\
\hline & $35-49$ Tahun & $0 \%$ \\
\hline & $>50$ Tahun & $1 \%$ \\
\hline \multirow[b]{3}{*}{ Penghasilan } & < Rp. 300.000 .000 & $62 \%$ \\
\hline & Rp. $300.000 .001-$ Rp. 2.500 .000 .000 & $29 \%$ \\
\hline & Rp. $2.500 .000 .001-$ Rp. 50.000 .000 .000 & $9 \%$ \\
\hline \multirow{18}{*}{$\begin{array}{l}\text { Perguruan } \\
\text { Tinggi }\end{array}$} & Universitas Negeri Surabaya & $40 \%$ \\
\hline & Universitas Airlangga & $14 \%$ \\
\hline & Universitas Islam Negeri Sunan Ampel & $8 \%$ \\
\hline & Universitas Ciputra & $4 \%$ \\
\hline & Universitas Surabaya & $3 \%$ \\
\hline & Universitas Wijaya Kusuma & $2 \%$ \\
\hline & Universitas Bhayangkara Surabaya & $2 \%$ \\
\hline & Universitas Nahdlatul Ulama Surabaya & $2 \%$ \\
\hline & Universitas Dr. Soetomo & $1 \%$ \\
\hline & Universitas Kristen Petra & $1 \%$ \\
\hline & Universitas 17 Agustus 1945 & $1 \%$ \\
\hline & Institut Teknologi Sepuluh Nopember & $8 \%$ \\
\hline & Institut Sains Dan Teknologi Terpadu & $3 \%$ \\
\hline & STIE Perbanas & $2 \%$ \\
\hline & STIE Mahardhika & $1 \%$ \\
\hline & STIESIA Surabaya & $2 \%$ \\
\hline & UPN Veteran Jatim & $3 \%$ \\
\hline & Politeknik Elektronika Negeri Surabaya & $3 \%$ \\
\hline
\end{tabular}

Sumber : Diolah penulis

Tabel 1 merupakan karakteristik responden berdasarkan jenis kelamin, umur, penghasilan dan perguruan tinggi tempat para responden lulus studi. Persentase responden laki-laki yang didapat pada penelitian ini sebesar $45 \%$ atau sebanyak 94 orang, sedangkan persentase responden perempuan sebesar 55\% atau berjumlah 117 orang dari 211 responden. Hal ini menunjukkan bahwa responden dengan jenis kelamin perempuan lebih mendominasi. Karakteristik responden berdasarkan umur didominasi usia 20-34 tahun sebanyak 209 orang atau sebesar 99\% dari total responden. Selain itu, 
Anglia Dinda Pramedi \& Nadia Asandimitra Haryono. Pengaruh Financial Literacy, Financial Knowledge, Financial Attitude, Income dan Financial Self Efficacy terhadap Financial Management Behavior Entrepreneur Lulusan Perguruan Tinggi di Surabaya

pada penelitian ini juga didominasi oleh responden dengan penghasilan pertahun sebesar < Rp. 300.000.000 yaitu sebanyak 130 orang. Responden lulusan Universitas Negeri Surabaya sebanyak 84 orang, alumni lulusan Universitas Airlangga sebanyak 29 orang, alumni lulusan Universitas Islam Negeri Sunan Ampel sebanyak 17 orang dan alumni lulusan Institut Teknologi Sepuluh Nopember sebanyak 16 orang. Sedangkan 65 responden tersebar pada 14 perguruan tinggi lainnya.

Hasil uji validitas dengan melihat nilai $r$ hitung $>r$ tabel $(0,3610)$. Terdapat 1 item pernyataan atau indikator yang tidak valid dikarenakan memiliki nilai $<0,3610$ sehingga harus dieliminasi. Namun, masih terdapat 26 indikator yang bisa dipakai sebagai alat ukur untuk menguji variabel bebas terhadap variabel terikat. Pada pengujian reliabilitas, sebuah variabel bisa dinyatakan reliabel apabila nilai cronbach alpha $>0,70$. Pada penelitian ini keenam variabel yaitu financial management behavior $(0,818)$, financial literacy $(0,716)$, financial knowledge $(0,750)$, financial attitude $(0,766)$, income $(1,000)$ dan financial self efficacy $(0,746)$ dinyatakan reliabel karena memiliki nilai $\mathrm{cr}>0,70$.

Uji oulier dapat dilihat melalui nilai mahalanobis $d$-squared dengan kriteria $\mathrm{p} 2>0,05$. Apabila data $<$ 0,05 maka dapat dikatakan outlier dan tidak dapat dilanjutkan ketahap berikutnya. Seluruh data penelitian atau sebanyak 211 data responden telah memenuhi uji outlier dikarenakan nilai p2 $>0,05$ dan dapat digunakan untuk pengolahan ditahap berikutnya.

Uji normalitas digunakan untuk melihat pola distribusi data dengan melihat Critical ratio (c.r) pada skewness value sebesar $\pm 2,58$. Hasil masih banyak indikator yang melebihi batas critical ratio (c.r) pada skewness value yaitu $\pm 2,58$. Indikator yang melebihi batas ring yaitu X1.1, X1.4, X2.1, X2.5, $\mathrm{X} 3.2, \mathrm{X} 3.4, \mathrm{X} 5.1, \mathrm{X} 5.4, \mathrm{Y} .2$, Y.4 sehingga ke 10 data tersebut harus dieleminasi atau dihapus. Dan terdapat 16 indikator yang berdistribusi normal yaitu X1.3, X1.5, X2.2, X2.3, X2.4, X3.1, X3.3, X3.5, Income, X5.2, X5.3, X5.5, X5.6, Y.1, Y.3, Y.5 karena memiliki nilai dalam rentang -2,58 hingga $+2,58$. Uji normalitas multivariate normality juga berdistribusi normal dikarenakan memiliki nilai 0,898 . Sehingga bisa disimpulkan bahwa asumsi univariate normality dan multivariate normality telah terpenuhi dan dapat digunakan untuk tahap selanjutnya.

Tabel 2.

HASIL AKHIR UJI GOODNESS OF FIT

\begin{tabular}{lccc}
\hline \multicolumn{1}{c}{ Goodness of Fit Indices } & Batas & Hasil & Keterangan \\
\hline GFI & $\geq 0,90$ & 0,924 & Baik \\
AGFI & $\geq 0,90$ & 0,868 & Marginal \\
TLI & $\geq 0,90$ & 0,902 & Baik \\
NFI & $\geq 0,90$ & 0,876 & Marginal \\
RMSEA & $0,05-0,08$ & 0,063 & Baik \\
\hline
\end{tabular}

Sumber: Output AMOS (data diolah)

Goodness of fit indices digunakan untuk menguji kelayakan model yang telah dibuat dengan melihat nilai dari GFI, AGFI, TLI, NFI dan RMSEA. Pada pengujian pertama, nilai GFI, AGFI, TLI dan NFI masih tergolong rendah dari nilai standart $\geq 0,90$. Nilai pada RMSEA juga masih di atas standar dan belum sesuai batas 0,05 - 0,08. Dikarenakan nilai belum sesuai dengan kriteria, maka dilakukan modification indices untuk memerbaiki model dengan melihat correlation error dan menghubungkan error yang memiliki nilai besar.

Tabel 2 hasil uji kelayakan model yang telah melalui modification indices. Model dapat dikatakan fit, karena terdapat 3 kriteria baik yaitu GFI 0,924 $\geq 0,90$, TLI 0,902 $\geq 0,90$, dan RMSEA 0,063. sedangkan 2 kriteria yang dinyatakan marginal yaitu AGFI 0,868 dan NFI 0,876. Dari hasil tersebut, uji kelayakan model dalam penelitian ini dapat diterima dan menghasilkan model akhir seperti pada gambar 2. 




Sumber: Hasil Pengolahan Data AMOS (data diolah)

Gambar 2. MODEL AKHIR SEM

Pengujian hipotesis digunakan untuk mengetahui apakah terdapat hubungan yang dihasilkan oleh variabel independen terhadap variabel dependen. Kriteria yang dipakai dalam pengujian hipotesis yaitu melakukan perbandingan nilai probabilitas signifikansi $(\mathrm{p})$ dengan taraf signifikansi 0,05 dan nilai critical ratio 2,00 .

Tabel 3 hasil pengujian hipotesis, di mana nilai $\mathrm{H} 1$ bisa diterima dengan nilai probabilitas signifikansi (p) $0,045, \mathrm{H} 2$ tidak diterima atau ditolak dengan nilai probabilitas signifikansi (p) $0,538, \mathrm{H} 3$ diterima dengan nilai probabilitas signifikansi (p) 0,006, H4 ditolak dengan nilai probabilitas signifikansi (p) 0,404 dan H5 ditolak dengan nilai probabilitas signifikansi (p) 0,453.

Tabel 3.

HASIL PENGUJIAN HIPOTESIS

\begin{tabular}{cllccccc}
\hline Hipotesis & & & & Estimate & S.E. & C.R. & P \\
\hline H1 & FMB & $<--$ & FL & .151 & .075 & 2.008 & .045 \\
H2 & FMB & $<---$ & FK & .062 & .043 & .616 & .538 \\
H3 & FMB & $<---$ & FA & .176 & .064 & 2.755 & .006 \\
H4 & FMB & $<---$ & Income & .011 & .013 & .835 & .404 \\
H5 & FMB & $<---$ & FS & .017 & .022 & .751 & .453 \\
& \multicolumn{7}{c}{ Squared Multiple Correlation } \\
FMB & \multicolumn{7}{c}{.518} \\
\hline
\end{tabular}

Sumber: Output AMOS (data diolah)

Setelah uji hipotesis selesai dilakukan, langkah selanjutnya yaitu melihat hasil nilai squared multiple correlations pada tabel 3. Nilai tersebut diperlukan untuk melihat seberapa besar kemampuan variabel terikat dalam memengaruhi variabel bebas. Berdasarkan tabel 3, nilai estimate variabel financial management behavior sebesar $0,518(51,8 \%)$. Hasil tersebut berarti bahwa besarnya pengaruh variabel dependen terhadap variabel independen sebesar 51,8\%. Hal ini menunjukkan bahwa sebesar $48,2 \%$ financial management behavior dipengaruhi oleh faktor lain di luar penelitian. Faktor yang bisa memengaruhi pengelolaan keuangan individu salah satunya yaitu locus of control seperti pada penelitian Laili Rizkiawati \& Asandimitra Haryono (2018) dan Arifin (2019). Selain itu, social economic status juga dapat menjadi faktor yang dapat memengaruhi perilaku keuangan seperti pada penelitian Herawati et al. (2018). 
Anglia Dinda Pramedi \& Nadia Asandimitra Haryono. Pengaruh Financial Literacy, Financial Knowledge, Financial Attitude, Income dan Financial Self Efficacy terhadap Financial Management Behavior Entrepreneur Lulusan Perguruan Tinggi di Surabaya

\section{Pengaruh Financial Literacy terhadap Financial Management Behavior}

Pengaruh antara variabel financial literacy dengan variabel financial management behavior berdasarkan uji hipotesis, terdapat pengaruh financial literacy terhadap financial management behavior. Hasil ini mendukung theory of planned behavior, bahwa seseorang dalam berperilaku dikarenakan memiliki niat dan tujuan yang dilatarbelakangi faktor informasi atau literasi (Ajzen, 1991). Hal tersebut juga berarti, apabila tingkat financial literacy yang di miliki oleh individu semakin tinggi, maka financial management behavior atau pengelolaan keuangan untuk usahanya juga akan meningkat. Sehingga, apabila responden memiliki pemahaman keuangan yang baik, maka responden akan mengetahui keuntungan maupun risiko yang dihadapi oleh usahanya dan dapat menentukan pengelolaan keuangan yang tepat. Salah satu faktor yang memengaruhi hasil tersebut yaitu, pada penelitian ini didominasi responden direntang umur 20-34 tahun, di mana pada umur tersebut generasi milenial masih rentan akan financial dan cenderung bergaya hidup konsumtif (Ardianto, 2020). Sehingga masih banyak dibutuhkan pemahaman terkait cara mengelola pendapatan untuk meningkatkan usaha dan mencari keuntungan sebesar-besarnya.

Hasil tersebut selaras dengan Herawati et al. (2018), Yap et al. (2016), Prihartono \& Asandimitra (2018), Herawati et al. (2018), Dayanti et al. (2020) serta Ida et al. (2020) bahwa semakin tinggi tingkat pemahaman mengenai keuangan, maka tanggung jawab dan pengambilan keputusan akan meningkat, sehingga dapat memengaruhi pengelolaan keuangan dengan lebih baik.

\section{Pengaruh Financial Knowledge terhadap Financial Management Behavior}

Merujuk pada hasil uji hipotesis, menunjukkan bahwa financial knowledge tidak memberi pengaruh terhadap financial management behavior. Dari hasil tersebut tidak terbukti bahwa tinggi rendahnya pengetahuan yang dimiliki oleh individu akan memengaruhi baik buruknya pengelolaan keuangan pada sebuah usaha. Hasil ini tidak sesuai dengan theory of planned behavior, bahwa pengetahuan dapat melatarbelakangi seseorang dalam berperilaku (Ajzen, 1991). Faktor yang memengaruhi hasil tersebut dapat dilihat pada pernyataan yang diberikan, Seperti pada pernyataan "saya memiliki pengetahuan mengenai suku bunga kredit yang dibebankan bank pada nasabahnya" sebanyak 109 responden menjawab "beberapa tahu" dan hanya mendapat presentase sebesar 2,91\%, selain itu pada pernyataan "saya memiliki pengetahuan mengenai kredit yang dikeluarkan oleh bank" sebanyak 160 responden juga menjawab "beberapa tahu". Hasil tersebut menunjukkan bahwa responden dengan lulusan perguruan tinggi tidak terlalu mengetahui terkait keuangan, khususnya perbankan yang memiliki peran dalam pengelolaan keuangan. Dari hasil yang diperoleh membuktikan bahwa memiliki pengetahuan keuangan atau financial knowledge saja tidak cukup untuk memengaruhi pengelolaan keuangan, namun dibutuhkan pemahaman lebih terkait keuangan untuk dapat mengelola keuangan individu maupun usaha dengan lebih baik. Hal ini sejalan dengan Rizkiawati \& Asandimitra (2018), Prihartono \& Asandimitra (2018), bahwa financial knowledge belum mampu untuk memengaruhi financial management behavior.

\section{Pengaruh Financial Attitude terhadap Financial Management Behavior}

Hasil pengujian hipotesis, financial attitude dapat memengaruhi financial management behavior. Dari hasil ini membuktikan bahwa baik buruknya financial attitude yang dimiliki oleh individu, dapat memengaruhi baik buruknya individu tersebut ketika melakukan pengelolaan keuangan atau financial management behavior pada usahanya. Hasil tersebut sesuai dengan theory of planned behavior, bahwa seseorang dalam berperilaku dipengaruhi oleh faktor personal salah satunya yaitu attitude (Ajzen, 1991). Faktor yang memengaruhi hasil tersebut yaitu para responden didominasi umur 20-34 tahun atau dapat dikatakan sebagai generasi milenial. Di mana pada umur tersebut terdapat ketidakselarasan antara cara berfikir akan keuangan dan bagaimana cara mencapai tujuan keuangannya (Putra, 2020). Sehingga generasi milenial membutuhkan pola pikir yang tepat untuk menyusun pengelolaan keuangan. Pola pikir tersebut akan memengaruhi bagaimana pengelolaan keuangan individu dapat berjalan lebih baik. Dalam penelitian ini responden mempunyai pola pikir yang cukup baik terkait keuangan, sehingga mampu untuk mengatur dan mengambil keputusan yang tepat untuk pengelolaan keuangan yang bijak. 
Hasil tersebut didukung Ramadhan \& Asandimitra (2019), Dayanti et al. (2020), Mahgfiroh et al. (2020), Rahmawati \& Haryono (2020), Rosyadah (2020), Komaria \& Ratnawarti (2018), Adiputra \& Patricia (2020), Prihartono \& Asandimitra (2018), Yap et al. (2016), Mien \& Thao (2015), Siswanti \& Halida (2020) yang menyatakan bahwa financial attitude yang dimiliki individu dapat memengaruhi financial management behavior seseorang.

\section{Pengaruh Income terhadap Financial Management Behavior}

Income tidak dapat memengaruhi variabel financial management behavior. Hasil ini juga tidak sesuai dengan theory of planned behavior, bahwa pendapatan merupakan salah satu faktor yang melatarbelakangi seseorang dalam berperilaku (Ajzen, 1991). Faktor yang mendasari dapat dilihat dari hasil pernyataan "ketika membeli suatu produk atau layanan, saya melakukan perbandingan terlebih dahulu" sebanyak 116 responden menjawab "selalu" dan "saya menyimpan uang untuk keperluan tidak terduga" 144 responden juga menjawab "selalu". Hal tersebut membuktikan bahwa responden atau entrepreneur yang memiliki pendapatan usaha mikro, kecil atau menengah sama-sama melakukan perbandingan pada produk maupun layanan yang akan dibeli agar tidak mengalami masalah keuangan pada usahanya. Selain itu para responden yang menyimpan uang untuk keperluan tidak terduga pada usaha seperti pembiayaan di masa depan juga tidak tergantung dengan tinggi rendahnya pendapatan usaha dalam satu tahun. Tinggi rendahnya pendapatan usaha tidak dapat memengaruhi pengelolaan keuangan pada para entrepreneur. Hasil ini juga didukung oleh Rizkiawati \& Asandimitra (2018), Rahmawati \& Haryono (2020), Adiputra \& Patricia (2020), Arifin (2019), bahwa income tidak dapat memengaruhi financial management behavior.

\section{Pengaruh Financial Self Efficacy terhadap Financial Management Behavior}

Finanacial self efficacy tidak dapat memengaruhi financial management behavior. Hasil tersebut menunjukkan bahwa baik buruknya pengelolaan keuangan atau financial management behavior individu tidak dipengaruhi oleh seberapa besar tingkat kepercayaan yang dimiliki individu tersebut. Hal ini tidak relevan dengan social cognitive theory, di mana teori tersebut menyatakan bahwa adanya keyakinan terhadap self efficacy sangat menentukan bagaimana cara seseorang dalam berperilaku (Bandura, 1977). Faktor yang menjadi penyebab hasil tersebut dikarenakan pada penelitian ini responden di dominasi usia 20-34 tahun, di mana pada umur tersebut para responden baru memulai untuk berwirausaha. Hal tersebut mengakibatkan masih banyak responden yang tidak percaya akan hal-hal yang terjadi di masa depan seperti pembiayaan usaha yang membutuhkan dana tidak terduga. Namun, hal tersebut tidak memengaruhi pengelolaan keuangan para responden, dalam penelitian ini para responden sudah cukup baik dalam mengelola keuangan usahanya. Sehingga, apabila responden memiliki keyakinan atau tingkat percaya diri yang buruk akan keuangan yang dimiliki, maka responden belum tentu melakukan pengelolaan keuangan yang buruk atau tidak bertanggung jawab pada usaha yang dimilikinya.

Hasil ini juga didukung oleh Nobriyani \& Haryono (2019) bahwa kuat atau lemahnya financial self efficacy yang dimiliki seseorang tidak memengaruhi financial management behavior karena keyakinan diri yang dimiliki individu belum dapat menjamin individu tersebut berbuat sesuai dengan tujuan keuangannya.

\section{KESIMPULAN}

Berdasarkan hasil analisis penelitian di atas, maka kesimpulan yang didapat yaitu financial literacy dan financial attitude mampu untuk memengaruhi financial management behavior untuk suatu usaha. Apabila tingkat pemahaman akan keuangan atau financial literacy yang dimiliki oleh seseorang tinggi, maka seseorang tersebut akan mengetahui keuntungan dan risiko yang akan dihadapi, sehingga mampu untuk menentukan pengelolaan keuangan usaha menjadi lebih baik. Baik buruknya financial attitude yang dimiliki oleh seseorang, juga akan memengaruhi cara seseorang dalam mengambil keputusan untuk mengelola keuangan pada usahanya. Financial literacy dan financial attitude yang dimiliki oleh responden sudah cukup baik, sehingga mampu untuk memengaruhi cara responden dalam mengelola keuangan usahanya. Variabel financial knowledge, income dan financial self 
Anglia Dinda Pramedi \& Nadia Asandimitra Haryono. Pengaruh Financial Literacy, Financial Knowledge, Financial Attitude, Income dan Financial Self Efficacy terhadap Financial Management Behavior Entrepreneur Lulusan Perguruan Tinggi di Surabaya

efficacy tidak mampu untuk memengaruhi financial management behavior. Artinya, bahwa tinggi rendahnya pengetahuan keuangan, pendapatan usaha pertahun dan tingkat kepercayaan akan keuangan yang dimiliki oleh seseorang tidak memengaruhi kemampuan seseorang tersebut dalam melakukan pengelolaan keuangan usahanya. Faktor yang memengaruhi hasil tersebut dikarenakan responden didominasi usia 20-34 tahun, di mana pada rentan umur ini, para responden masih memulai untuk berwirausaha, sehingga pengetahuan keuangan dan tingkat kepercayaan akan hal-hal yang terjadi dimasa depan seperti pembiayaan jangka panjang masih tergolong kurang, namun hal ini tidak mengurangi kebijakan dan tanggung jawab para entrepreneur dalam mengelola keuangan usahanya.

Pada penelitian ini, dua faktor yang terbukti mampu untuk memengaruhi financial management behavior entrepreneur lulusan perguruan tinggi di Surabaya yaitu financial literacy dan financial attitude. Maka peneliti menyarankan kepada para entrepreneur untuk dapat meningkatkan financial literacy dan financial attitude sehingga berguna untuk pengelolaan keuangan atau financial management bahvior pada individu, maupun untuk pengembangan usaha dimasa depan. Bagi peneliti selanjutnya, diharapkan menggunakan variabel bebas lain yang diduga mampu memberi pengaruh pada variabel financial management behavior. Sehingga dapat menambah pemahaman mengenai pertanyaan penelitian yang sedang dilakukan dan juga dapat menjadi sebuah perbandingan antar variabel yang menjadi faktor pengaruh financial management behavior. Karena besaran kontribusi yang diberikan oleh variabel financial literacy dan financial attitude pada financial management behavior hanya sebesar $51,8 \%$, sedangkan $48,2 \%$ sisanya dipengaruhi oleh variabel lain. Hal ini membuktikan bahwa dalam peningkatan pengelolaan keuangan pada entrepreneur untuk pengembangan usaha dibutuhkan faktor lainnya seperti locus of control (Arifin, 2019), social economic status (Herawati et al., 2018) dan financial socialization agent (Ramadhan \& Asandimitra, 2019). Selain itu, pada penelitian berikutnya disarankan untuk melakukan penambahan jumlah responden dan memperluas jangkauan populasi yang tidak hanya ditujukan pada entrepreneur lulusan perguruan tinggi di Surabaya supaya data yang didapat lebih maksimal. Karena terdapat batasan pada penelitian, maka data responden yang didapat menumpuk pada beberapa karakterisitik saja, seperti karakteristik pada responden yang didominasi usia 20-34 tahun. Hal ini dikarenakan kurang meluasnya populasi pada penelitian.

\section{DAFTAR PUSTAKA}

Adiputra, i G., \& Patricia, E. (2020). The Effect of Financial Attitude, Financial Knowledge, adn Income on Financial Management Behavior. Tarumanagara International Conference on the Applications of Social Sciences and Humanities (TICASH 2019), 42(1), 15-24. https://doi.org/10.1007/s10591-019-09520-x

Ajzen, I. (1991). The Theory of Planned Behavior The Theory of Planned Behavior. Organizational Behavior and Human Decision Processes, 50(2), 179-211. https://doi.org/10.1016/07495978(91)90020-T

Ardianto, P. (2020). Literasi Keuangan Harus Ditingkatkan Terutama di Kalangan Milenial. Investor.Id. (https://investor.id/finance/literasi-keuangan-harus-ditingkatkan-terutama-dikalangan-milenial, diakses pada 29 Maret 2021)

Arifin, A. Z. (2019). The Influence of Financial Knowledge, Control and Income on Individual Financial Behavior. European Research Studies Journal, 20(July), 635-648.

Bandura, A. (1977). Self-Efficacy: Toward A Unifying Theory Of Behavioral Change. Psychological Review, 84(2), 191-215.

Budiarto, T. (2015). Peranan Mata Kuliah Kewirausahaan Dalam Meningkatkan Minat Mahasiswa Untuk Berwirausaha. Kompasiana. (https://www.kompasiana.com/paansiih/peranan-matakuliah-kewirausahaan-dalam-meningkatkan-minat-mahasiswa-untuk-berwirausaha, diakses 
pada 21 November 2020).

Chen, H., \& Volpe, R. P. (1998). An Analysis of Personal Financial Literacy Among College Students. Financial Services Review, 7(2), 107-128.

Dayanti, F. K., Susyanti, J., \& S, M. K. A. B. (2020). Pengaruh Literasi Keuangan, Pengetahuan Keuangan Dan Sikap Keuangan Terhadap Perilaku Manajemen Keuangan Pada Pelaku Usaha UMKM Fashion Di Kabupaten Malang. E-Jurnal Riset Manajemen, 9(13), 160-174.

Dirjen Dikti Kemendikbud. (2020). Direktorat Kemahasiswaan. Direktorat Jenderal Pendidikan Tinggi Kementerian Pendidikan Dan Kebudayaan RI. (http://dikti.go.id/mahasiswa/, diakses pada 17 November 2020).

Forbes, J., \& Kara, S. M. (2010). Confidence Mediates How Investment Knowledge Influences Investing Self- Efficacy. Journal of Economic Psychology, 31, 435-443.

Garman, E. T., \& Forgue, R. (1985). Personal Finance. USA Houghton Mifflin company.

Herawati, N. T., Candiasa, I. M., Yadnyana, I. K., \& Suharsono, N. (2018). Factors That Influence Financial Behavior Among Accounting Students in Bali. International Journal of Business Administration, 9(3), 30. https://doi.org/10.5430/ijba.v9n3p30

Humaira, I., \& Sagoro, E. (2018). Pengaruh Pengetahuan Keuangan, Sikap Keuangan, dan Kepribadian terhadap Perilaku Manajemen Keuangan pada Pelaku UMKM Sentra Kerajinan Batik Kabupaten Bantul. Jurnal Nominal, VII(1), 96-110.

Ida, \& Dwinta, C. Y. (2010). Pengaruh Locus of Control, Financial Knowledge, Income Terhadap Financial Management Behavior. Jurnal Bisnis Dan Akuntansi, 12(3), 131-144.

Ida, Zaniarti, S., \& Wijaya, G. E. (2020). Financial Literacy, Money Attitude, Dan Financial Management Behavior Generasi Milenial. Jurnal Muara Ilmu Ekonomi Dan Bisnis, 4(2), 406413.

Kementerian Koperasi dan UKM. (2018). Data UMKM. Departemen Koperasi Dan UKM. (http://www.depkop.go.id/data-umkm, diakses pada 19 Oktober 2020).

Kementerian Koperasi dan UKM. (2020). Kemenkop Dan UKM Berharap Lulusan Perguruan Tinggi DiTuntut Berkarya Kreatif dan Inovatif. Kementerian Koperasi Dan UKM. (http://kemenkopukm.go.id/read/kemenkop-dan-ukm-berharap-lulusan-perguruan-tinggidituntut-berkarya-kreatif-dan-inovatif, diakses pada 16 Oktober 2020).

Kencana, M. R. B. (2020, August 6). OJK Nilai Literasi Keuangan Harus Dikenalkan Sejak SD. Liputan 6. (https://www.liputan6.com/bisnis/read/4324192/ojk-nilai-literasi-keuangan-harusdikenalkan-sejak-sd, diakses pada 17 November 2020).

Kholilah, N. Al, \& Iramani, R. (2013). Studi Financial Management Behavior pada Masyarakat Surabaya. Journal of Business and Banking, 3(1), 69-80.

Komaria, N., \& Ratnawarti, K. (2018). Pengaruh Financial Attitude, Financial Knowledge, Dan Personal Income Terhadap Personal Financial Management Behavior Pada Karyawan Generasi Milenial Pt. Petrokimia Gresik. Journal of Chemical Information and Modeling, 53(9), 16891699.

Lown, J. M. (2011). 2011 oustanding AFCPE® Conference paper: Development and validation of a Financial Self-Efficacy Scale. Journal of Financial Counseling and Planning, 22(2), 54-63. 
Anglia Dinda Pramedi \& Nadia Asandimitra Haryono. Pengaruh Financial Literacy, Financial Knowledge, Financial Attitude, Income dan Financial Self Efficacy terhadap Financial Management Behavior Entrepreneur Lulusan Perguruan Tinggi di Surabaya

Mahgfiroh, cheny roghibatul, Susyanti, J., \& Wahono, B. (2020). Pengaruh Financial Attitude, Financial Knowledge, Dan Parental Income Terhadap Financial Management Behavior Dengan Love Of Money Sebagai Variabel Intervening (Studi Kasus Pada Mahasiswa-Mahasiswi Perguruan Tinggi Negeri Dan Swasta Di Kota Malang). E-Jurnal Riset Manajemen, 9(6), 4863.

Masdupi, E., \& Rasyid, R. (2020). Financial Management Behavior at Productive Age Community in Bukittinggi. 4th Padang International Conference on Education, Economics, Business and Accounting (PICEEBA-2 2019), 124, 673-681.

Mien, N. T. N., \& Thao, T. P. (2015). Factors Affecting Personal Financial Management Behaviors : Evidence from Vietnam. Second Asia-Pasific Conference on Global Business, Economics, Finance and Social SCiences, 10-12.

Nobriyani, A. P., \& Haryono, N. A. (2019). Faktor-Faktor yang Memengaruhi Financial Management Behavior pada Keluarga TKI di Kabupaten Ponorogo. Jurnal Ilmu Manajemen Universitas Negeri Surabaya, 7(3), 841-856.

Nugraheny, D. E., \& Meiliana, D. (2020). Data Kependudukan 2020: Penduduk Indonesia 268.583.016 Jiwa. Kompas. (https://nasional.kompas.com/data-kependudukan-2020-pendudukindonesia-268583016-jiwa, diakses pada 21 Oktober 2020).

Otoritas Jasa Keuangan. (2014). Literasi Keuangan. OJK. https://www.ojk.go.id/id/kanal/edukasidan-perlindungan-konsumen/Pages/Literasi-Keuangan.aspx, diakses pada 19 November 2020).

Otoritas Jasa Keuangan. (2017). Undang-Undang Nomor 20 Tahun 2008 Tentang Usaha Mikro, Kecil, dan Menengah. Ojk.Go.Id. (https://www.ojk.go.id/sustainablefinance/id/peraturan/undang-undang/Pages/Undang-Undang-Republik-Indonesia-Nomor-20Tahun-2008-Tentang-Usaha-Mikro,-Kecil,-dan-Menengah.aspx, diakses pada 31 Mei 2021).

Prihartono, M. R. D., \& Asandimitra, N. (2018). Analysis Factors Influencing Financial Management Behaviour. International Journal of Academic Research in Business and Social Sciences, 8(8), 308-326. https://doi.org/10.6007/ijarbss/v8-i8/4471

Purwanto, A. (2020). Potret dan Tantangan UMKM di Indonesia. Kompas. (https://kompaspedia.kompas.id/baca/paparan-topik/potret-dan-tantangan-umkm-di-indonesia, diakses pada 17 November 2020).

Purwidianti, W., \& Tubastuvi, N. (2019). The Effect of Financial Literacy and Financial Experience on SME Financial Behavior in Indonesia. Jurnal Dinamika Manajemen, 10(1), 40-45. https://doi.org/10.15294/jdm.v10i1.16937

Putra, Y. S. (2020). Survei: Generasi Milenial Ingin Menabung, Tapi Banyak yang Tidak Bisa. Liputan 6. (https://www.liputan6.com/bisnis/read/4440728/survei-generasi-milenial-inginmenabung-tapi-banyak-yang-tidak-bisa, diakses pada 29 Maret 2021).

Putri, M. H., \& Pamungkas, A. S. (2019). Pengaruh Financial Knowledge , Locus of Control dan Financial Self Efficacy Terhadap Financial Behavior. Jurnal Manajerial Dan Kewirausahaan, I(4), 890-889.

Rahmawati, N. W., \& Haryono, N. A. (2020). Analisis Faktor yang Memengaruhi Financial Management Behavior dengan Mediasi Locus of Control. Jurnal Ilmu Manajemen, 8(2), 549563. 
Ramadhan, A. Y., \& Asandimitra, N. (2019). Determinants of Financial Management Behavior of Millennial Generation in Surabaya. Jurnal Minds: Manajemen Ide Dan Inspirasi, 6(2), 129. https://doi.org/10.24252/minds.v6i2.9506

Redaksi. (2019). Kelompok Sarjana Dominasi Pengangguran Jatim, Ini Angkanya. Expost News. (https://expostnews.com/kelompok-sarjana-dominasi-pengangguran-jatim-ini-angkanya/, diakses pada 14 Oktober 2020).

Rizkiawati, N. L., \& Asandimitra, N. (2018). Pengaruh Demografi, Financial Knowledge, Financial Attitude, Locus of Control Dan Financial Self-Efficacy Terhadap Financial Management Behavior Masyarakat Surabaya. Jurnal Ilmu Manajemen (JIM), 6(3).

Rosyadah, K. (2020). The Influence of Financial Knowledge, Financial Attitudes, And Personality To Financial Management Behavior For Micro, Small And Medium Enterprises Typical Food of Coto Makassar. JHSS (Journal of Humanities and Social Studies), 04(02), 152-156.

Siswanti, I., \& Halida, A. M. (2020). Financial Knowledge, Financial Attitude, And Financial Management Behavior: Self-Control as Mediating. The International Journal of Accounting and Business Society, 28(01), 105-132.

Sodikin, S. S., \& Riyono, B. A. (2014). Akuntansi Pengantar 1 (sembilan). Yogyakarta: UPP STIM YKPN.

Sugiyanto, T., Radianto, W. E., Christian, T., \& Dewi, L. (2019). Financial Literacy, Financial Attitude, And Financial Behavior of Young Pioneering Business Entrepreneurs. Advances in Economics, Business and Management Research, 100, 353-358.

Ulya, F. N., \& Sukmana, Y. (2019). BPS: Pengangguran Meningkat, Lulusan SMK Mendominasi. Kompas. (https://money.kompas.com/read/2019/11/05/155358926/bps-pengangguranmeningkat-lulusan-smk-mendominasi, diakses pada 17 November 2020).

Yap, R. J. C., Komalasari, F., \& Hadiansah, I. (2016). The Effect of Financial Literacy and Attitude on Financial Management Behavior and Satisfaction. International Journal of Administrative Science \& Organization, 23(3). 